\title{
The improvement of preschoolers' social emotional skills
}

\section{Khusnidakhon KHUJAMATOVA ${ }^{1}$}

Kokand University

\begin{tabular}{l} 
ARTICLE INFO \\
\hline Article history: \\
Received January 2021 \\
Received in revised form \\
15 January 2021 \\
Accepted 20 February 2021 \\
Available online \\
7 March 2021 \\
\hline
\end{tabular}

\section{Keywords:}

Emotional development

Behavior

Early childhood,

Effects

Principles

Relationships.

\begin{abstract}
This article is based on giving essential information about young children's social emotional improvement and its significance. Social emotional development is important to a child's success in school and in life. Social emotional development means and notions, opinions are showed on how to use and promote it. Social emotional skills can be expressed in early childhood in each classroom. This can be done in different lessons and activities. Social emotional development can be promoted by embedding it in all areas of the day.

Nowadays, other priorities have been seen in early childhood classrooms and at home. Some researchers believe this has resulted in a lack of promotion of social emotional development in young children. This paper focuses on the explore academic pushdown, technology and children, and limited free time, including recess. These may influence a young child's social emotional ability therefore they may present more challenging behaviors. Three social emotional development programs are explored. Social emotional development is so significant in the early years of a child's life. Families and teachers have to comprehend its significance.
\end{abstract}

2181-1415/CC 2021 in Science LLC.

This is an open access article under the Attribution 4.0 International (CC BY 4.0) license (https://creativecommons.org/licenses/by/4.0/deed.ru)

\section{Maktabgacha tarbiyachilarning ijtimoiy hissiy ko'nikmalarini takomillashtirish}

\author{
Калит сўзлар: \\ Ijtimoiy hissiy rivojlanish \\ Xulq-atvor \\ Erta bolalik \\ Ta'sirlar \\ Tamoyillar
}

\section{АННОТАЦИЯ}

Ushbu maqola yosh bolalarning ijtimoiy hissiy yaxshilanishi va uning ahamiyati to'g'risida muhim ma'lumotlar berishga asoslangan. Ijtimoiy hissiy rivojlanish bolaning maktabda va hayotda muvaffaqiyati uchun muhimdir. Ijtimoiy hissiy rivojlanish vositalari va tushunchalari, undan qanday

\footnotetext{
${ }^{1}$ Independent researcher, Lecturer of the Department of Education, Kokand University, Kokand, Uzbekistan
} 


\begin{abstract}
foydalanish va targ'ib qilish to'g'risida fikrlar bildiriladi. Ijtimoiy hissiy qobiliyatlarni har bir sinfda erta bolalik davrida ifodalash mumkin. Buni turli darslarda va tadbirlarda qilish mumkin. Ijtimoiy hissiy rivojlanishni kunning barcha jabhalarida singdirish orqali targ'ib qilish mumkin.

Hozirgi kunda boshqa ustuvor vazifalar erta bolalik davridagi sinflarda va uyda kuzatilmoqda. Ba'zi tadqiqotchilar, buning natijasida yosh bolalarda ijtimoiy hissiy rivojlanishni rag'batlantirishning yetishmasligiga olib keldi, deb hisoblashadi. Ushbu maqolada akademik pasayish, texnologiyalar va bolalarni o'rganish, bo'sh vaqt, shu jumladan ta'tilga e'tibor qaratilgan. Bular yosh bolaning ijtimoiy hissiy qobiliyatiga ta'sir qilishi mumkin, shuning uchun ular qiyinroq hatti-harakatlarni namoyon qilishi mumkin. Uchta ijtimoiy hissiy rivojlanish dasturlari o'rganildi. Ijtimoiy hissiy rivojlanish bola hayotining dastlabki yillarida juda muhimdir. Oilalar va o'qituvchilar uning ahamiyatini tushunishlari kerak.
\end{abstract}

\section{Совершенствование социальных эмоциональных навыков дошкольников}

Ключевые слова:
Социально-
эмоциональное развитие
Поведение
Раннее детство
Эффекты
Принципы
Отношения

\section{АННОТАЦИЯ}

Статья основана на предоставлении важной информации о социальном эмоциональном улучшении маленьких детей и его значении. Социально-эмоциональное развитие важно для успеха ребенка в школе и в жизни. Показаны средства и понятия социально-эмоционального развития, мнения о том, как его использовать и продвигать. Социальноэмоциональные навыки могут быть выражены в раннем детстве в каждом классе. Это можно сделать на разных уроках и занятиях. Социально-эмоциональному развитию можно способствовать, если включить его во все области дня.

В настоящее время в классах для детей младшего возраста и дома рассматриваются другие приоритеты. Некоторые исследователи считают, что это привело к тому, что у детей младшего возраста не было стимулирования социального эмоционального развития. В этой статье основное внимание уделяется изучению неуспеваемости, технологий и детей, а также ограниченного свободного времени, включая перемены. Они могут повлиять на социальные эмоциональные способности маленького ребенка, поэтому они могут проявлять более вызывающее поведение. Исследуются три программы социального эмоционального развития. Социально-эмоциональное развитие имеет огромное значение в первые годы жизни ребенка. Семьи и учителя должны понять его значение.

It is important to show social emotional development in young children. It is vital to promote this development in the early childhood classroom and at home. Social emotional 
skills contain problem solution, taking turns, empathy, decision-making, and relationship building (Durlak\&Weissberg, 2011; Fettig, Santos, \& Shaffer, 2012). All of these skills and more are essential for present and future relationships and academic success. If children have competent social-emotional skills, their secondary-performance and completion is higher, they will be more helpful in their careers, and become a more successful adult (Domitrovich, Durlack, Staley, \&Weissberg, 2017). It is important that social-emotional skills be promoted in the early years. If the stage is not set at an early age, many children will show challenging behaviors. Children must be taught appropriate ways to communicate and handle their emotions[1-5].

This article focuses on the importance and effects of social emotional development. It takes a look at how to promote these skills in the classroom and at home and why they may not be in the forefront of today's early childhood classrooms. First, an overview is provided of what social-emotional skills are and why they are important. Building relationships and practicing intentional teaching is also examined. A developmentally appropriate early childhood classroom must promote social emotional learning effectively[6-9]. In recent years there have been some roadblocks. Possible reasons why social-emotional skills may not be assisted as well as they should be showed. These include academic pushdown, effects of technology, and lack of recess and spare time. Finally, three social-emotional learning programs are discussed. These programs intentionally teach social-emotional skills. Using a social emotional program helps to create a supportive environment where the focus is on the development of social-emotional skills.

Social-emotional development has a great role throughout a child's lifetime. Many early childhood theorists have stressed the significance of social emotional development. Albert Bandura, Jean Piaget and Lev Vygotsky believed in the power of social interaction and its importance in the process of learning and development (Baylor \& Kim, 2006; Devries, 1997). Bandura's social cognitive theory was founded in social interaction. He believed children learned by observing the behavior of others. Children must be provided with choices and the power over their own learning. Bandura believed that by allowing children to gain independence, their self-efficacy would be enhanced. This efficacy is impacted by social experiences (Baylor \& Kim, 2006).

Piaget's and Vygotsky's social theories also encourage peer interactions and relationships. Piaget believed that much could be gained in the cognitive improvement area based on social experiences. These experiences are with both adults and peers. The goal of these experiences is for a child to gain autonomy and self-regulation[10-14]. Both the adult relationship and the child relationship should be respectful, trustful and cooperative, along with encouraging empathy and being one of mutual affection and trust. Piaget believed that by creating such relationships a child's social skills were strengthened (DeVries, 1997). DeVries (1997) developed five principles for early childhood education, based on his own experiences in preschool-grade two. These principles focus on relationships, cooperation, conflict resolution and community.

DeVries (1997) states that teachers should develop lessons and activities based on the interests of the children. Piaget's sociocognitive theory supports these principles. He believed that by promoting social development, cognitive development is also being promoted (DeVries, 1997). Piaget and Vygotsky both believed that adults should provide a socially interactive classroom that promotes social emotional development. This can be 
provided through group games, decision-making, negotiating, interacting, voting and developing of classroom rules (Baylor \& Kim, 2006; Devries, 1997).

Statistics from the National Center for Children in Poverty (Cooper, Masi, \& Vick, 2009) show that young children's development and school readiness are affected by social-emotional problems. Children need to have adequate social emotional skills to be successful in the classroom and to become successful adult citizens. If children's social and emotional needs are not met, including the promotion of social emotional skills, they are more likely to experience delinquency and mental health problems (Cooper et al., 2009).

Social emotional development has many definitions. According to The Center on the Social Emotional Foundations for Early Learning (CSEFEL), social emotional development is the development that happens in children birth through age 5 that allows a child to have trusting relationships with both adults and peers; be able to express emotions in appropriate ways; and become independent and comfortable to investigate their surroundings (Ashdown \& Bernard, 2012). According to Ashdown and Bernard (2012) there are five core social emotional competencies[15-18]. These are: self-awareness, social awareness, self-management, relationship skills and responsible decision-making. These are vital to young children's welfare. Social emotional skills include self-confidence, goal setting, empathy, responsible decision-making, concentration, persistence, attentiveness, effective communication and problem-solving (Ashdown \& Bernard, 2012; Durlak\&Weissberg, 2001; Fettig, Santos, \& Shaffer, 2012).

Social emotional development in a young child is vital to ensuring a fruitful outcome in life. All children have to engage in activities that assist social skills. Children who are not socially emotionally competent are at risk for challenging behavior in childhood and adulthood. Early childhood educators have the chance to present social skills in every classroom. Early childhood teachers can use and show social emotional skills in the classroom by providing children with a safe, nurturing, and predictable atmosphere. Creating an environment where children feel valued and independent is significant. Social emotional skills will be identified naturally by permitting children ample time to interact with one another through child-led play, including recess. If young children do not enhance social emotional competence, it will be difficult for them to have academic achievement. They may also exhibit challenging behaviors in the classroom. Some specific ways that early childhood teachers can provide an appropriate environment is by intentionally teaching classroom expectations in a respectful way. For instance, at the beginning of the school year, children can help develop rules and expectations. By having children involved in this process, they are more likely to take ownership over them and want to meet those expectations. Another way to support consistent expectations in a predictable environment is through the use of visual supports. Young children must comprehend the pattern of their school day, so they are not feeling unsure about what is coming next. One way to help with this is to incorporate a daily visual schedule. This schedule should be posted in the classroom and readily accessible to all children. Each part of the day is depicted using a picture. This allowschildren to know the activities throughout the day, decreasing any anxiety they mayhave about the school day. When children feel safe and secure, it is easier for them to actively participate in the classroom.

Children also feel valued and can become more independent when trusting, nurturing relationships are formed. When teachers create these types of relationships, children's social-emotional development benefits, along with their cognitive development 
(Funk \& Ho, 2018). According to Funk and Ho (2018), early childhood teachers can create trusting, nurturing relationships with children by being warm affectionate and caring. Creating strong relationships with students can begin even before the school year starts. Home visits are often used in early childhood programs. Home visits provide families and children with an opportunity to meet and engage with the teacher. These are conducted in the child's home. This is beneficial, as a child's home is usually their safe, comfortable haven. During home visits, a teacher can visit with families and get to know children by doing a fun activity with them. Once in the classroom, relationships need to continue to form. Strong relationships with students and families correlate with the development of social skills. If children feel safe in the classroom environment, they will feel comfortable enough to gain independence.

Another essential aspect of relationship building is between teachers and families. Families are a child's first teacher. The teacher can gain insight into a child's preferences and interests by communicating with families. One of the most important factors in social emotional development is attachment with parents, especially mothers (Cooper et al., 2009). Parents and caregivers of young children may have risk factors, which may influence a child's social emotional development. This lack of development may cause children as young as 3 to present challenging behaviors (Cooper et al., 2009). Creating meaningful relationships with families will be useful if their child begins exhibiting challenging behaviors. Families will be more willing to work together to incorporate strategies to help the child. Family relationships can be fostered by having on-going, open communication. For instance, teachers can maintain a communication notebook. A communication notebook can go between school and home. Teachers can write a child's activities for the day and any situation that may have occurred. The families also have the opportunity to write back to the teacher. Many children come to school on a school bus and teachers do not have the opportunity to speak with families face to face. Communication notebooks are one way to communicate effectively with parents.

Early childhood teachers can contribute positively to a child's family. They may give information about families of the significance of social emotional skills and how to define and show them at home. Many parents may understand the significance of these skills, but may not know how to promote them. At home, parents can provide an environment with appropriate behavioral expectations. They can interact positively with their child and encourage their child to do the same with others. Early childhood teachers can provide families with strategies to use at home and encourage them to use them with consistency. Early childhood teachers can also work together with families by informing them of expectations in the classroom. These things can be communicated through a weekly or monthly newsletter. Activities, which promote social emotional development, can be suggested on a monthly calendar. Newsletters and calendars sent home periodically help the relationship between teachers and families.

At present, some things have gotten in the way of social emotional development being a focus in the early childhood classroom. Many classrooms are focusing more on academic success of young children. Some teachers are forgetting how social emotional competency can lead to higher academic achievement. Early childhood teachers need to stay current on the trends and issues related to young children. Academic achievement in early childhood is becoming more of a focus by policymakers. By providing developmentally appropriate learning opportunities for young children, this achievement 
will still happen. Early childhood teachers need to remain focused on how children learn best and not give into the pressure of academic pushdown.

Technology has become more prevalent in our educational system in recent years. More classrooms are using technology as a teaching strategy. Early childhood classrooms are able to incorporate technology into play. By doing so, social emotional development is still being promoted. Young children are exposed to technology very early. If technology is used as a teaching tool, some social skills can be promoted. These include cooperation, independence, motivation and self-esteem (McCarrick\&Xiaoming, 2007).Early childhood teachers have to remain cognizant of the time that children spend on technological devices and the time spent interacting with adults and peers. Allowing children free play, including recess, is essential in promoting social emotional development. Early childhood teachers can conduct and provide free, unstructured play daily. As recess time for young children diminishes, so does the time for children to interact socially. Early childhood teachers need to research information about the impacts of minimizing recess time. So many valuable skills are being developed during this time. Recess provides children with necessary, unstructured time to interact with their peers. By providing this time, they will be able to focus better in the classroom.

Young children also should have spare time in the classroom. Children should have the opportunity to make choices in their play. Early childhood classrooms can provide these choices by maintaining center areas. These center areas can consist of Block Center, Dramatic Play Center, Art Center, Reading Center, Science Center, and Math \& Literacy Center. By providing a variety of learning activities and materials, children will be focused and engaged. By engaging in a variety of activities and materials, all developmental domains will be promoted, including social-emotional. Through unstructured play children learn to negotiate, take turns, problem-solve and self-regulate. These are all important skills young children need in order to be successful in the classroom and in life. Parents, caregivers, teachers and any other stakeholders must comprehend the necessity of social emotional skills and how to illustrate them in early childhood.

\section{CONCLUSION}

Social emotional competence is important for a young child to improve in order to be a successful adult. Social emotional skills contain goal setting, empathy, responsible decision-making, confidence, concentration, persistence, effective communication and problem solving, among others (Durlak\&Weissberg, 2001; Fettig et al., 2012). More early childhood classrooms are placing their focus on academic success rather than social emotional enhancement. It is essential to write that children are more likely to show challenging behaviors if they do not have social emotional competency. Social emotional skills can be embedded into the classroom throughout the day. There are also social emotional learning programs available for early childhood classrooms. Many of these support activities to intentionally teach social emotional skills. Some of these also includes a family component. By being intentional about teaching social emotional skills, young children will be more likely to be competent in these skills, exhibit less challenging behaviors and be more knowledgeable and lucky adults.

Also, much research work has been done on the topic of social emotional improvement, additional investigation should be done. There is still a lack of consensus on the impacts of technology on social emotional development. Research findings have 
concluded both that technology is detrimental to social emotional development and that technology can promote social emotional development (McCarrick\&Xiaoming, 2007). Przybylski and Weinstein (2019) discuss that the research done on the connection between digital media and a child's development is lacking. It is not proven that limiting digital media would have positive impacts on their enhancement.

\section{REFERENCES:}

1. Almon, J., Carlsson-Paige, N., \& McLaughlin, G. (2015). Reading instruction in Kindergarten: Little to gain and much to lose. Alliance for Childhood and Defending the Early Years, 1- 11.

2. Arda, T. \&Ocak, S. (2012). Social competence and promoting alternative thinking strategies - PATHS Preschool Curriculum. Educational Sciences: Theory \& Practice, 12(4), 2691-2698.

3. Ashdown, D. \& Bernard, M. (2011). Can explicit instruction in social and emotional learning skills benefit the social-emotional development, well-being, and academic achievement of young children? Early Childhood Education Journal, 39(6), 397-405.

4. Baylor, A. \& Kim, Y. (2006). A social-cognitive framework for pedagogical agents as learning companions. Educational Technology, Research and Development, 54(6), 569-596.

5. Benedict, E., Horner, R., \& Squires, J. (2007). Assessment and implementation of positive behavior support in preschools. Topics in Early Childhood Education, 27(3), 174-192.

6. Bloodworth, M., Graczyk, P., Payton, J., Wardlaw, D., \&Weissberg, R. (2000). Social and emotional learning: A framework for promoting mental health and reducing risk behavior in children and youth. TheJournalofSchoolHealth, 70 (5), 179-185.

7. Bohn, C. \& Pellegrini, A. (2005). The role of recess in children's cognitive performance and school adjustment. Educational Researcher, 34(1), 13-19.

8. Brooks, A-M., Coyne, I., Hanafin, S., McDonnel, F., \&Rouine, H. (2009). A whole-child perspective assessment guide for early years settings. Community Practitioner, 82(10), 2225.

9. Broyles, L., Fox, L., Hemmeter, M., \& Jack, S. (2007). A program-wide model of positive behavior support in early childhood settings. Journal of Early Intervention, 29(4), 337- 355.

10. Buntain-Ricklefs, J., Cook, C., Low, S., \&Smolkowski, K. (2015). Promoting socialemotional competence: An evaluation of the elementary version of Second Step. Journal of School Psychology, 53(6), 463-477. 14-17.

11. Chang, R. \& Coward, F. (2015). More recess time, please! Phi Delta Kappan, 97(3),

12. Cooper, J., Masi, R. \& Vick, J. (2009). Social-emotional development in early childhood: What every policymaker should know. ColumbiaUniversity: NationalCenterforChildreninPoverty.

13. Cortes, R., Domitrovich, C., \& Greenberg, M. (2007). Improving young children's social and emotional competence: A randomized trial of the preschool "PATHS" curriculum. TheJournalofPrimaryPrevention, 28(2), 67-91.

14. Domitrovich, C., Durlak, J., Staley, K., \&Weissberg, R. (2017). Social-emotional competence: An essential factor for promoting positive adjustment and reducing risk in school children. ChildDevelopment, 88(2), 408-416. 
15. Durlak, J., Dymnicki, A., Schellinger, K., Taylor, R., \&Weissberg, R. (2011). The impact of enhancing students' social and emotional learning: A meta-analysis of school-based universal intervention. ChildDevelopment, 82(1), 405-432.

16. Durlak, J. \&Weissberg, R. (2011). Promoting social and emotional development is an essential part of students' education. HumanDevelopment, 54(1), 1-3.

17. KHUSNIDAKHON, K. (2021). THE IMPORTANCE OF ENHANCING SOCIAL SKILLS OF PRESCHOOLERS.

18. Mansurovna, K. K., \& Ilkhamovna, F. N. (2020). THEORETICAL BASES OF FORMATION OF SOCIAL CONSCIOUSNESS IN PRESCHOOL OLDER CHILDREN. European Journal of Research and Reflection in Educational Sciences Vol, 8(6). 